九州大学学術情報リポジトリ

Kyushu University Institutional Repository

\title{
Overview of Rice Production System in the Mekong Delta-Vietnam
}

Hien Nguyen, Thi Minh Laboratory of Quantitative Analysis of Agricultural Economics, Devision of Industrial Organization of Agribusiness, Department of Agricultural and Resource Economics, Graduate School of Bioresource and Bioenvironmental Sciences, Kyushu University

Kawaguchi, Tsunemasa

Laboratory of Quantitative Analysis of Agricultural Economics, Devision of Industrial Organization of Agribusiness, Department of Agricultural and Resource Economics, Faculty of Agriculture, Kyushu University

https://doi.org/10.5109/24474

出版情報: 九州大学大学院農学研究院紀要. 47 (1)，pp.221-231，2002-10-30. Kyushu University バージョン：

権利関係 : 


\title{
Overview of Rice Production System in the Mekong Delta-Vietnam
}

\author{
Hien NGUYEN Thi Minh* and Tsunemasa KAWAGUCHI
}

\author{
Laboratory of Quantitative Analysis of Agricultural Economics, Division of Industrial \\ Organization of Agribusiness, Department of Agricultural and Resource Economics, \\ Faculty of Agriculture, Kyushu University, Fukuoka 812-8581 \\ (Received June 28, 2002 and accepted July 12, 2002)
}

\begin{abstract}
Rice production is of major importance to Vietnam. It concerns $70 \%$ of labor force, the country holds at present around $10 \%$ of world rice market. Half of production and $70 \%$ of exported rice come from the Mekong Delta. Since the end of the decade of 80 s, Vietnam has changed its economic policy to market-oriented economy and has got a rapid economic growth, particularly rice production has gained important achievements. From a food-deficit country, Vietnam becomes the second largest rice cxporters in the world (since 1996, over 3 million tons per year has been exported). However, nowadays, rice production faces a lot of difficulties such as natural disasters, fluctuation of input and output prices, low export price, small farm scale, lack of capital, degraded equipment for pre-- and post-harvesting. Furthermore, fluctuation of price in the world market influences directly on rice production in Mekong Delta. Besides, weakness of rice exporting systern still restrains domestic production, and not only reduces profit of farming households but also loses national budget. In this context, like in other Asian countries, analysis and identification of production cost, paddy cost-price, economic efficiency of different agents in rice marketing channel are necessary and very important for the reliable and appropriate policy of Vietnamese authorities in short and long-run development.
\end{abstract}

\section{INTRODUCTION}

Rice occupies a main part of agricultural land in Vietnam. For the whole country, approximately 4.2 millions hectares of 7.9 millions hectares of total agricultural land is covered by rice; of which 1.95 millions hectares concentrated in the Mekong Delta, where only $22.3 \%$ of total population live (Sanh, 1998; GSO, 2000a)

In recent years, thanks to the renovation of Vietnamese economic policy, agricultural production in the Mekong Delta has been greatly developed. Rice production has become a very important income source for rice farming households who contribute to more than $50 \%$ of total paddy production and to nearly $70 \%$ of exported rice volume. Generally, life of peasants is clearly improved (GSO, 2000b; Minot, 2000)

However socio-economic problems have been raised for some recent years in the Mekong Delta which is not only the concern of the government but also of economic research institutions: economic disparity between agricultural sector and others; between peasants and other professional groups and among peasants. Although living standard of the most part of population has been improved, the average GDP per capita has remained low (250 USD). In the rural regions, the percentage of poor households is still high at a

\footnotetext{
* Laboratory of Quantitative Analysis of Agricultural Economics, Division of Industrial Organization of Agribusiness, Department of Agricultural and Resource Economics, Graduate School of Bioresource and Bioenvironmental Sciences, Kyushu University.
} 
level of $20.9 \%$ (World bank in Vietnam, 1999). Most of farmers, especially rice producers, have continued facing a difficult and poor life. Meanwhile a part of farmers has become richer and significantly improved their life conditions thanks to benefits coming from a market economy where they are the winners in competition. Moreover, land accumulation by a part of farming households has been raised in some recent years and become socio-economic problem.

The objectives of the paper are as follows: 1) To overview the status of agricultural production and the role of rice in national economy; 2) To describe the history of rice production in the Mekong Delta; 3) To assess the current situation of rice production in Mekong Delta for future development.

\section{OVERVIEW OF THE STATUS OF AGRICULTURAL PRODUCTION}

Being one of the developing nations, Vietnam is still poor. Basically, Vietnam economy has depended on agricultural production at low-developed level, of which cultivation of food crop for national security has always been an important issue. However, in recent years, under new economic policies towards market-oriented economy applied from 1986 , there has been achieved a lot of progress.

Agriculture is still the most important economic sector since there are $77 \%$ inhabitants living in rural areas and agriculture population occupies $68 \%$ of whole country population (GSO, 2000a). Agriculture is also responsible for a remarkable share of total export value that contributes to national capital accumulation needed for structural change of economy towards industrialisation and modernisation.

Over fifteen years of implementation of renovation, agriculture has generated important achievements and greatly contributed in overcoming the difficulties during the financial crisis in the region, as well as creating an initial base for sustainable development and continuous growth. The first important issue is that Vietnam agriculture has quickly moved from self-sufficient economy to commercial production system. In 2000, total food output reached 34.5 million tons (of which paddy rice accounted for 32.6 million tons) with an average increase of 1.3 million tons per year. The average food availability was $435 \mathrm{~kg}$ per capita in 2000. The areas of crops with high-economic value have increased remarkably. Agricultural export value has increased from 1745.8 millions USD to 2833 million USD during 1995-2000 (GSO, 2000a).

Total annual agricultural export value has increased by $16 \%$, accounting for $40 \%$ of agricultural GDP. Many Vietnamese agricultural products have a strong marketing potential in regional and international markets. Agriculture continues to play a dominant role in the economy, accounting for about $53 \%$ of employment and $50 \%$ of GDP.

\section{IMPORTANCE OF RICE AND TRENDS IN RICE PRODUCTION AND TRADE}

In Vietnam, rice is the staple food crop and locally originated, though many new varieties have been adopted. The Vietnamese culture has developed with rice growing practices. Generally, there are three rice crops in the year: the winter-spring (Dong Xuan$\mathrm{DX}$ ), the summer-autumn (He Thu- HT), and wet long season (lua mua- M). Commonly, farmer practice winter-spring rice and summer rice on the fields. The seasonal calendars 
for these rice crops greatly vary among regions (North, Central, South) and among the ecosystems (irrigation, rainfed lowland, upland, and deep-water or flood prone areas). There were yield gaps among these regions, rice seasons, and ecosystems. In 2000 total rice growing area was 7,670 thousand ha, with average paddy yield of 4.3 ton per ha, and gross production of 32,700 thousand tons (GSO, 2001). Both the rice growing area and rice yield increased continuously. However before 1989, the increase in rice yield was faster than that in the growing area. In the year 1990s increase in yield was slow down and similar with that in rice growing area.

In 1989, Vietnam became a net rice exporter. The rice production exported increased rapidly between 1995 and 1999 (Table 1). In 2000, the exported production reached level of 4,050 thousand tons of milled rice (GSO, 2001).

Table 1. Rice production in Vietnam (1980-1999)

\begin{tabular}{llccccc}
\hline \multicolumn{1}{c}{ Indicator } & Unit & $\mathbf{1 9 8 0}$ & $\mathbf{1 9 8 5}$ & $\mathbf{1 9 9 0}$ & $\mathbf{1 9 9 5}$ & $\mathbf{1 9 9 9}$ \\
\hline Total output & Million ton & 11.6 & 15.9 & 19.2 & 25.0 & 34.1 \\
Sown area & 1000 ha & 5576.9 & 5719.4 & 6018.8 & 6775.0 & 7648.1 \\
Paddy land & 1000 ha & - & 4297 & 4270 & 4225 & 4200 \\
Yield & Ton/ha & 2.08 & 2.78 & 3.19 & 3.69 & 4.11 \\
Net Export & Million ton & -0.2 & -0.3 & 1.6 & 2.0 & 4.5 \\
Population & Million. Per & 53.6 & 59.9 & 65.9 & 72.1 & 76.6 \\
Rice production & Kg/capita & 146 & 178 & 195 & 232 & 275 \\
per capita & & & & & & \\
\hline
\end{tabular}

Source: GSO, statistical yearbooks 1990, 1995, 1996, 1999, GSO, IID 2000

\section{HISTORY OF RICE PRODUCTION IN THE MEKONG DELTA}

Rice production has been taking place a long time in Vietnam, particularly in the Mekong Delta along with the development of the farming systems, settlement process, land reclamation, canal excavation, socio-economic situation as well as the policies of government (Sanh, 1998). An overview of the major events affecting to the rice production systems is presented in table 2 .

\section{THE SITUATION OF RICE PRODUCTION SYSTEM IN THE MEKONG DELTA}

\section{Land distribution for rice production}

In 1999, the total agricultural land area is 9.345 million hectares, while total rice area occupies 7.655 million hectares. As rice bowl of the country, Mekong Delta takes $49 \%$ of total rice cultivated land and contributes $50.5 \%$ of total paddy output, corresponding to 17 million tons while there is only $23.3 \%$ of total agricultural population living in the Mekong Delta (GSO, 2000a). The paddy output of the Mekong Delta has remarkably increased due to the new progress of cultivation technology which has been intensively applied parallel to the improvement of irrigation systems that allow to grow up to three rice crop a year. The distribution of rice production system in the Mekong Delta is presented in the Figure 1 
Table 2. History of rice production and related evens in the Mękong Delta

\begin{tabular}{|c|c|}
\hline Period & Rice production progress and evens \\
\hline 10000 years ago & $\begin{array}{l}\text { - Formation of the Mekong Delta } \\
\text { - Oc-Eo stage and pioneer Vietnamese settlement: rice collection for food } \\
\text { and preliminary rice cultivation }\end{array}$ \\
\hline $1705-1858$ & $\begin{array}{l}\text { The early stage of the exploitation of the Mekong Delta under the Nguyen } \\
\text { dynasty, excavation of three main canals, land reclamation and } \\
\text { development of floating rice cultivation. }\end{array}$ \\
\hline $1858-1954$ & $\begin{array}{l}\text { - Land reclamation: increase of cultivated area for rice due to many } \\
\text { canals excavated } \\
\text { - Double transplanting and single transplanting of rice with local rice } \\
\text { varieties. } \\
\text { - Rice plantation establishment by French colonists }\end{array}$ \\
\hline 1954-1975 & $\begin{array}{l}\text { The war period } \\
\text { - } 1966 \text { : introduction of high yielding varieties (IR5 and IR8) from } \\
\text { International Rice Research Institute (IRRI) } \\
\text { - Since 1968: shift from single rice cropping to double rice cropping on } \\
\text { the alluvial soil and the high topography areas } \\
\text { Machines have applied for land preparation and irrigation in rice cultivation } \\
\text { Brown plant hopper (BPH) outbreak in } 1972 \\
\text { Some rice areas are left fallow because of war's destroy }\end{array}$ \\
\hline $1975-1979$ & $\begin{array}{l}\text { End of the war, peasants returned to their farm and was continuing to } \\
\text { produce rice } \\
\text { - 1977: browm plant hopper damaged the local rice varieties } \\
-\quad 1978 \text { : very serious flooding and damage rice production }\end{array}$ \\
\hline 1979-1981 & $\begin{array}{l}\text { Collective farm establishment stage } \\
-\quad \text { 1979: shifting from BPH sensitive rice varieties to BPH tolerant rice } \\
\text { varieties } \\
\text { - Area of double rice crop increases } \\
-\quad \text { Enlarged the irrigation canal } \\
-\quad \text { Reallocation of land to no land and small-land peasants } \\
-\quad \text { Large fallow land areas were exploited for rice production (including } \\
\text { the acid sulphate soil and forest) }\end{array}$ \\
\hline $1981-1988$ & $\begin{array}{l}\text { Break out of the contract policy and carrying out the reform } \\
-\quad \text { De-collectivization of farms and redistribution of land to peasant } \\
-\quad \text { Reform of land policy (1998) } \\
-\quad \text { Shifting from centrally planned economy to market oriented economy } \\
\text { - Free domestic markets for commercialized rice and agricultural } \\
\text { materials } \\
\text { - Shift from double crop to triple rice cultivation (beginning of 1986) }\end{array}$ \\
\hline 1989-now & $\begin{array}{l}\text { - Fixed land tax system } \\
\text { - Vietnam has exported rice in } 1989 \text { and became the second largest rice } \\
\text { exporter in the world } \\
\text { - 1991-1993: restriction of rice exportation quota granted for State } \\
\text { Owned Enterprises } \\
\text { - 1990-1994: Diversification of cropping pattern in agriculture besides the } \\
\text { tradition of rice intensive cultivation } \\
\text { - Introduction and releasing of many high yielding modern rice varieties, } \\
\text { integrated pest management (IPM), mechanization and balanced } \\
\text { fertilizer application } \\
\text { - Application of floor price for paddy (1995) } \\
\text { - 1995-1996: relaxation of quota level for rice exportation and private } \\
\text { companies } \\
\text { - 1996-1997: natural disaster damaged thousands of hectare of rice } \\
\text { 1998: Vietnamese rice gains the good price competitiveness in the world } \\
\text { rice market and remain a second position in the rice exportation in } 5 \\
\text { years }\end{array}$ \\
\hline
\end{tabular}




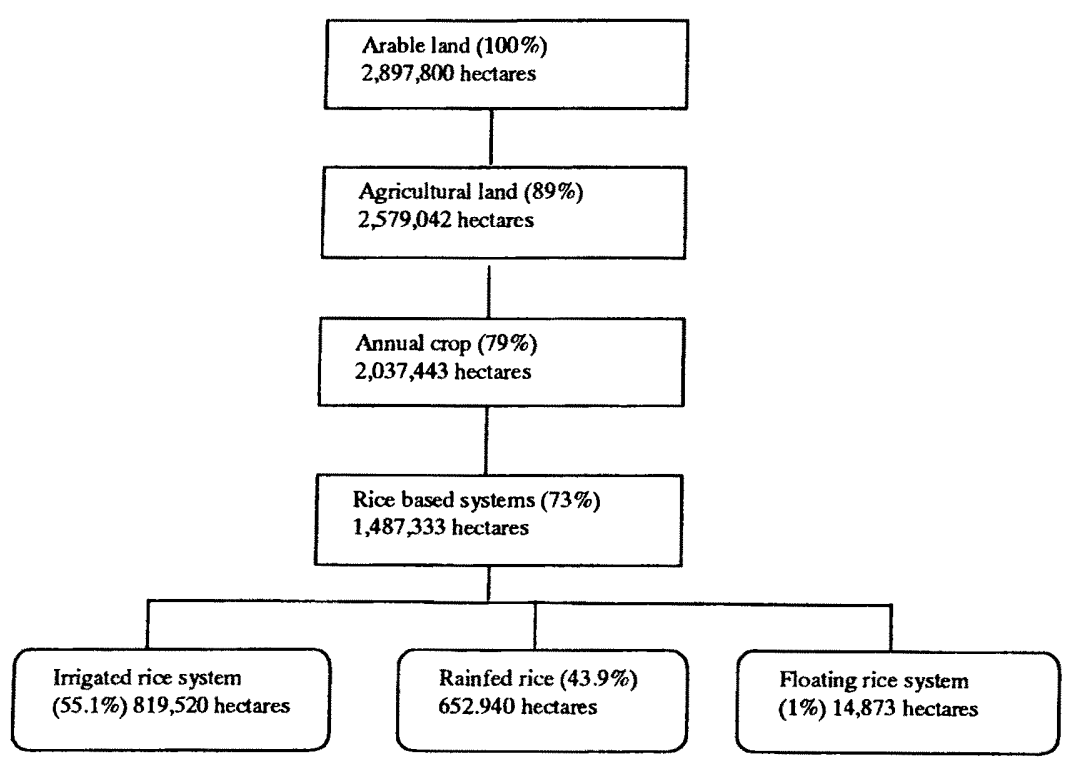

Fig. 1. Distribution of rice production system in the Mekong Delta

\section{Rice Cropping Systems in the Mekong Delta}

There are three main rice seasons in the Mekong river delta (Table 3, figure 2). Two of the seasons (HT and M) coincide with the rainy season which typically starts in May and lasts until November. The annual rainfall in the study area varies from 1600 to $2000 \mathrm{~mm}$. The three rice seasons, in various combinations governed by hydrology, rainfall pattern and availability of irrigation, constitute the variety of rice-based cropping systems practiced in the Mekong river delta.

The major rice cropping systems in this area are the single rice crop (SC), double rice crop (DC) and triple rice crop (TC) systems (Table 4). The single rice crop is invariably in the $M u a(\mathrm{M})$, which has traditionally been the rainfed rice cropping system using local, traditional varieties with a longer growth period. It is practiced mainly in the tidally-inundated coastal area subjected to salinity intrusion prior to the rainy season. The double

Table 3. Rice season in the Mekong Delta

\begin{tabular}{cllc}
\hline & \multicolumn{1}{c}{ Season } & Planting & Harvesting \\
\hline Dong Xuan $(D X)$ & Winter-Spring & Nov/Dec & Feb/Mar \\
He Thu $(H T)$ & Summer-Autumn & May/Jun & Aug/Sep \\
Mua $(M)$ & Rainy Season & Jul/Aug & Dec/Jan \\
\hline
\end{tabular}

Source: Cuu Long Delta Rice Research Institute, 2001 


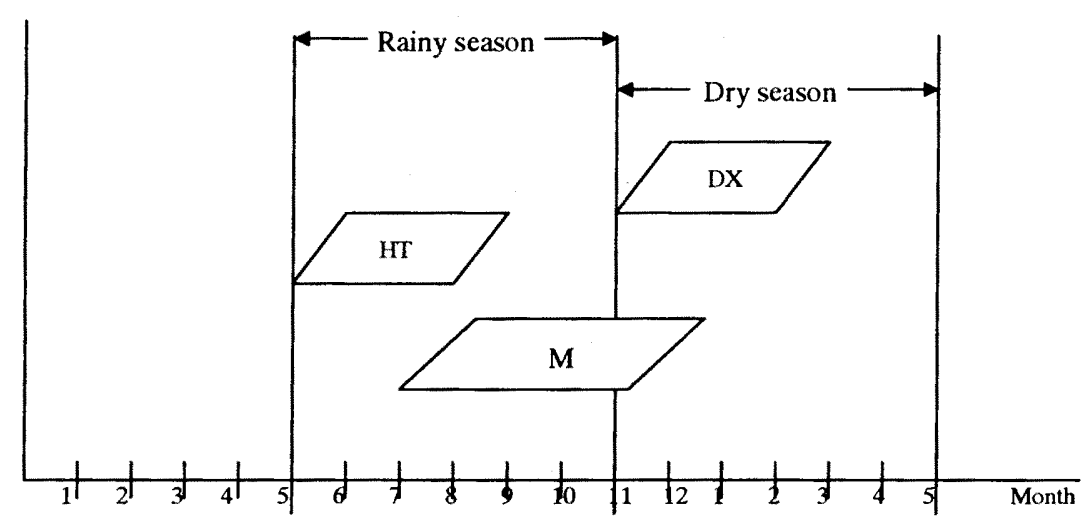

Fig. 2. Rice season in the Mekong Delta

cropping system may be in the Dong Xuan-He Thu (DX-HT) or the He Thu-Mua (HT-M) system. The DX crop, which planted at the end of the rainy season, needs to be irrigated. In areas affected by deep flooding during the rainy season, the second crop (HT) is planted earlier in April, depends on pump-irrigation for its water, and is harvested before the onset of the flood. In areas where flooding is not severe or commences later, the HT crop is planted in May/June and by use of rain water. The HT-M system is typically practiced in the salinity affected areas and in areas where irrigation is not available. Both crops are rainfed. Hence the crop calendar varies each year, depending on the onset of the rainy season. The rice crops may be planted using the transplanting or the direct seeding method. In the direct seeding method, the seeds are either sown onto dry fields prior to the start of the rainy season (dry direct seeding) or pre-germinated seeds may be sown onto wet fields (wet direct seeding). The HT crop is generally wet or dry direct seeded while the $\mathrm{M}$ crop may be transplanted or wet direct seeded. The triple crop system combines all three rice seasons (DX-HT-M) and is practiced in limited riverine areas with favorable hydrological conditions and availability of irrigation for the DX crop.

Table 4. Major rice cultivating systems in the Mekong Delta

\begin{tabular}{c|c|c}
\hline & Cropping Type & Rice Seasons \\
\hline 1. & Single Rainfed & Mua (M) \\
2. & Double Irrigated & Dong Xuan (DX) - He Thu (HT) \\
3. & Double Rainfed & He Thu $(\mathrm{HT})-$ Mua (M) \\
4. & Triple Irrigated-Rainfed & Dong Xuan (DX) - He Thu (HT) -Mua (M) \\
\hline
\end{tabular}

Source: Cuu Long Delta Rice Research Institute, 2000

\section{Rice production practice in the Mekong Delta}

Rice is the major annual crop in Vietnam. In recent years, rice has become Vietnam's 
principal agricultural export commodity and a chief source of foreign exchange. Vietnam has become the second largest exporter of rice in the world, trailing only Thailand. The Mekong River Delta is the most fertile rice growing area of Vietnam and accounts for nearly half of Vietnam's total rice production (Pingali, 1998).

Two general types of rice varieties are grown. Traditional long duration rice varieties generally require longer growing seasons but produce higher quality grain. Modern short duration rice varieties require shorter growing periods but produce lower quality rice. Short duration rice varieties are normally grown in the winter-spring season to take advantage of the longer daylight hours and shorter maturation time. Long duration rice varieties are usually planted in the summer-autumn season when shorter daylight hours require the cropping season to be longer. Households that are closer to rivers or have access to irrigation can plant a third rice crop of short duration varieties. Those with adequate capital and access to water sometimes plant watermelons or vegetables in the third season instead of a short duration rice crop. Otherwise, fields are left fallow during this third season.

Traditional rice variety seeds are typically germinated in rice nurseries. Seedlings are subsequently transplanted. Rice fields are usually cleared prior to transplanting. Paddy straw and stubble are often burned during this stage to improve field sanitation and kill weed plants and weed seeds. The field is fallow for one or two days before plowing or harrowing. Fields are then flooded, usually by rainfall, with some farmers supplementing water supplies by irrigation. The water is then drained, leaving fields wet for transplanting. Transplanting is labor intensive and has to be completed within a very short period in order to ensure uniform crop maturity. Fertilizers are broadcast. Weeds can be pulled by hand or treated with herbicides. Insecticides and fungicides are applied periodically during the season, typically by one person using a backpack sprayer. Additional broadcast applications of fertilizers are often made during the season as well. Rice is harvested by hand when mature, then threshed and dried in the open. When rainfall is heavy and drying is infeasible, farmers often sell their entire harvest to millers on site.

Modern rice variety seeds are sown by broadcast rather than grown in nurseries and then transplanted. Water is let into the field as the seeds germinate. Seedlings that have been sown too close together are uprooted and replanted to ensure sufficient space for adequate growth. In other respects, modern short duration rice varieties are cultivated in the same way as traditional long duration varieties. Direct seeding has advantage in saving labor cost. Further, the adoption of herbicide has been in association with the adoption of direct sowing. The common constrain to the adoption of direct seeding is the consistency on crop establishment.

\section{Equipment and mechanization for rice production}

The owned equipments and facilities for rice production are still poor in the Mekong Delta. Most of farmers own the simple tools as sprayer, water pump with low value of investment because rice production in the Mekong Delta is priorities for family consumption, then the surplus is used for exchanging on the market. As a result, the part of output used for re-investment of machine is limited. Further, the cultivated land is scarce and limited, especially in the poor farming household. However, facing with lack of labor in the peak time, the rich farmers invest on machines such as tractor, plough 
machine, threshing machine, and others. They are usually concerned with off-farm activities or provide agricultural services as land preparation, threshing, drying or water pumping.

Table 5. Popular High Yielding Rice Varieties in the Mekong Delta of Vietnam (1998)

\begin{tabular}{llcr}
\hline Variety Name & \multicolumn{1}{c}{ Origin } & $\begin{array}{c}\text { Duration } \\
\text { (days) }\end{array}$ & $\begin{array}{c}\text { Harvested Area } \\
\text { (\%) }\end{array}$ \\
\hline IR50404-57 & IRRI & 95 & 15 \\
OMCS94 & IR59606-119 (IRRI) & 95 & 14 \\
OM1490 & OM606/IR44592 & 90 & 12 \\
OM1706 & OM90-9/OM33-1 & 95 & 8 \\
IR64 & IRRI & 105 & 10 \\
OM1723 & OM554/IR50401 & 95 & 10 \\
IR56279 & IRRI & 95 & 5 \\
IR66707 & IRRI & 105 & 5 \\
OM997 & OM554/IR50401 & 95 & 8 \\
IR9729-67 & IRRI & 95 & 3 \\
IR62032-189 & IRRI & 105 & 1 \\
OMFi1 & MRC19399 (Philippines) & 105 & 0.9 \\
OM1633 & NN6A/IR32843 & 95 & 0.7 \\
OM1271 & OM89/IR68 & 95 & 0.7 \\
\hline
\end{tabular}

Source: Cuu Long Rice Research Institute, 2000

\section{Adoption of new rice varieties}

Rice varieties were changed year by year. The introduction of short-term modern rice varieties is significant to switch from single crop to double or triple rice crops per years. With maturity duration is shorter than 115 days, these varieties can avoid the early flash flood in the Mekong Delta, so that can limit the reduction of paddy yield. With the widespread adoption of modern rice varieties, the paddy yield is relatively high and stable, selling price is reasonable. Almost all varieties introduced in the Mekong Delta can be grouped into 4 main categories: Modern rice-short term; Modern rice-medium term; Traditional rice (local rice); Glutinous rice/aromatic rice. The popular high yielding varieties in the Mekong Delta of Vietnam is presented in the table 5.

Traditional rice varieties still remain to be grown in some regions due to good quality, high selling price and high adapt ability to the annual cycle of flood waters, and are reliant on the flood's silt and nutrients to maintain soil fertility. These traditional rice cropping systems produce stable returns yet require little to no tillage and use little to no of expensive puts such as chemical fertilizers and pesticides. However, the area under floating rice has decreased over recent years from 500,000 ha in 1975 to less than 50,000 ha in 1995.

Farmers in the Mekong Delta have developed more than 1,000 traditional rice varieties. These are highly valued for their taste, fetching higher prices than high-yield rice 
varieties, and often form an essential ingredient of traditional dishes at cultural festivals, such as Tet (Vietnamese New Year). However, these traditional varieties have been rapidly replaced by high-yield rice varieties promoted through agricultural extension programs; less than 150 traditional varieties are now being cultivated in the Mekong Delta.

\section{Rice yield}

The area under modern rice varieties in the winter-spring, summer-autumn, and a part of the wet season-long duration crop has increased by $15-20 \%$ in recent years. On the average, winter-spring rice yields are highest ( $5.27 \mathrm{t} / \mathrm{ha}$ ) followed by yields of summer-autumn (3.72 t/ha) and wet season-long duration rice (3.18t/ha). Floating rice yields are low (1.5t/ha). The area and yield of rice also varies by provinces. The table 6 presents the area, yield and out put of rice by each province in the Mekong Delta in 1999.

Table 6. Area, yield, and gross output of rice by province in the Mekong Delta

\begin{tabular}{cccc}
\hline & $\begin{array}{c}\text { Area } \\
\text { (thousand hectare) }\end{array}$ & $\begin{array}{c}\text { Paddy yield } \\
\text { (ton/hectare) }\end{array}$ & $\begin{array}{c}\text { Output } \\
\text { (Million ton) }\end{array}$ \\
\hline Mekong Delta & $\mathbf{3 9 8 5 . 2}$ & $\mathbf{4 . 0 9}$ & $\mathbf{1 6 . 2 9 5}$ \\
Long An & 441.2 & 3.45 & 1.523 \\
Dong Thap & 442.7 & 4.69 & 2.076 \\
An Giang & 462.9 & 4.54 & 2.100 \\
Tien Giang & 286.4 & 4.55 & 1.301 \\
Vinh Long & 224.2 & 4.31 & 0.966 \\
Ben Tre & 101.1 & 3.23 & 0.327 \\
Kien Giang & 521.3 & 3.89 & 2.026 \\
Can Tho & 466.6 & 4.24 & 1.979 \\
Tra Vinh & 232.6 & 3.61 & 0.839 \\
Soc Trang & 356.5 & 4.23 & 1.508 \\
Bac Lieu & 205.9 & 3.91 & 0.805 \\
Ca Mau & 243.8 & 3.46 & 0.844 \\
\hline
\end{tabular}

Source: Statistical year book 2000

\section{Marketing system of rice in Mekong Delta}

More than two-thirds of the paddy harvested in the Mekong Delta is sold. Private assemblers account for more than $95 \%$ of paddy purchases from farmers (Minot, 2000). Then assemblers generally sell paddy to medium and large-scale millers, wholesalers and state owned enterprises. Wholesalers frequently reported buying rice from and selling rice to other wholesalers. Wholesalers also supply retail traders. State owner enterprises (SOEs) play an important role in wholesale trade. The SOEs operate on a much larger scale than private traders, in terms of volume of trade, size of assets and storage facilities. SOEs also are important suppliers to wholesalers in the food-deficit regions. The marketing channel in Mekong Delta is illustrated in the Figure 3

\section{Some main problem in production and marketing of rice in the Mekong Delta}

There are many constraints for rice production in different agro-ecological regions in 


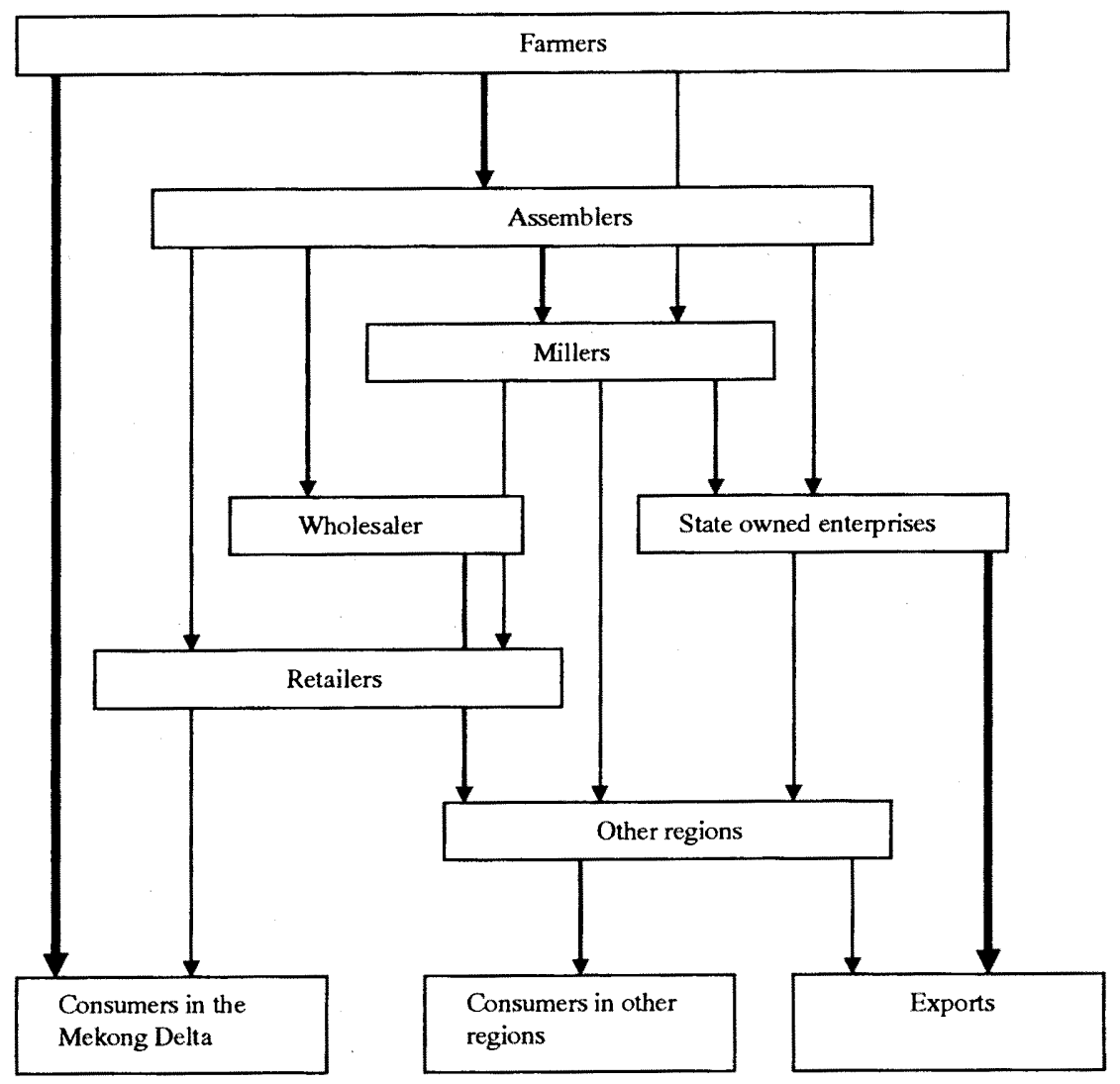

Fig. 3. Rice marketing channels in the Mekong Delta

Mekong Delta such as the shortage labor in peak time, shortage of machines for mechanization in main activities like land preparation, or harvest. Plot of agricultural land in general and that of paddy in particular are small, and they create many difficulties in mechanization as well as irrigation.

Facilities for grading, storage and processing are in shortage. Processing technology is very obsolete, and it leads to higher cost, and lower quality. About $10 \%$ of harvested rice have been lost in farmers' preservation facilities and 3\% at State facilities. Farmer blamed poor processing and storage technology for seriously affecting the quality and quantity of the remaining harvest.

The poor quality of the rice exported and the limited capacity of domestic activities are main reasons to expand export markets. Sixty four percent of rice exported is of low and medium quality. Therefore the price is low and the export turnover is unsatisfactory. Commercial and concentrated zones for rice export in order to produce better quality rice and to minimize production as well as transportation cost have not been established yet. In order to expand the markets and earn more from export, both exporters and producers 
will have to work on improving the quality of the rice. Suggestions on how to improve the quality of rice for export includes the idea that rice cultivation region exclusively for exports should be developed. Rice processing and preserving techniques should also be improved.

Rice yields are still low compared with other countries like China, Indonesia, Japan. Even though rice is the main product and $70 \%$ of rice export of Vietnam come from the Mekong Delta, but rice growers are still poor and very poor. Farmers did not want to expand their rice production, and as the result, larger number of farmer have already stopped their rice cropping and shifted out of rice into more high value added crops such as flowers, vegetables and fruits.

Farmers complained about low farm gate price compared to production cost. Food prices rose higher, but remained low in comparison with price of other commodities and services. Low and fluctuated rice price and high input price, adding with other problems, have been constrained to rice growing farmers. After the bumper crops, farmers are still not happy because they do not know whom to sell or how much to sell.

Another remaining difficulty is, as usual, capital shortages. Due to capital shortages, rice exporters' purchasing capacity was restricted. Limited access to credit, information for marketing and under-developed private marketing are also main problems. There is still lack of farmer's access to market information on price. Addition, due to uncomfortable weather and natural calamity, weakness and inefficiency in introduction of new technology and limitation of knowledge of a part of farming households result many risks to the rice producers. As a consequence, their income and benefit of rice production are still low and unstable.

\section{REFERENCES}

General Statistical Office (GSO) 1995 Statistical yearbook 1994. Statistical Publishing House, Hanoi General Statistical Office (GSO), Statistical yearbook 1995 Statistical Publishing House, Hanoi General Statistical Office (GSO), Statistical yearbook 1996 Statistical Publishing House, Hanoi General Statistical Office (GSO) 2000a Statistical yearbook 1999. Statistical Publishing House, Hanoi General Statistical Office (GSO) 2000b Vietnam Living Standard Survey 1997-1998. Statistical Publishing House, Hanoi

General Statistical Office (GSO) 2001 Statistical yearbook 2000. Statistical Publishing House, Hanoi General Statistical Office (GSO), Department of Agriculture, Forestry and Fishery (DAFF) 2000 Statistical data of Vietnam Agriculture, Forestry and Fishery 1975-2000. Statistical Publishing House, Hanoi.

General Statistical Office (GSO), Integrated and Information Department (IID) 2000 Statistical data of Vietnam socio-economy 1975-2000. Statistical Publishing House, Hanoi.

Minot N. and F. Goletti 2000 Rice market Liberalization and poverty in Vietnam Research report 114. IFPRI (International Food Policy Research Institute), Washington, D. C.

Pingali, P. L., V-T. Xuan, N. T. Khiem, and R. V.Gerpacio 1998 Prospects for sustaining Vietnam's re-acquired rice exporter status. Food Policy 22.

Sanh, N. V., V. T. Xuan, T. A. Phong 1998 History and future of farming systems in the Mekong Delta. In "Development of farming systems in the Mekong Delta of Vietnam" Edited by Vong Tong Xuan, Shigeo Matsui. Ho Chi Minh city publishing house, Sai gon time group, Vietnam Asia Pacific Economic Center, Ho Chi Minh city.

World Bank in Vietnam 1999 Vietnam attacking poverty, Joint report of the Government of Vietnam-Donor-NGO poverty working group. Publishing Department of Ministry of Culture and Information, Hanoi. 